https://journal.uwgm.ac.id/index.php/abdimasmahakam

E-ISSN: 2549-5755

Januari 2020, Vol. 4 No. 01

Received: Oktober 2019

Accepted: Desember 2019

Published: Januari 2020

Article DOI: http://dx.doi.org/ 10.24903/jam.v4i1.810

\title{
Penyuluhan Pengelolaan Sampah Perkotaan Berbasis Rumah Tangga di Desa Labuhan Sumbawa
}

\author{
Ieke Wulan Ayu \\ Fakultas Pertanian,Universitas Samawa \\ iekewulanayu002@gmail.com \\ Yadi Hartono \\ Fakultas Pertanian,Universitas Samawa \\ yadihartono82@yahoo.com \\ Dwi Mardhia \\ Fakultas Peternakan dan Perikanan,Universitas Samawa \\ kemang.kuneng@gmail.com \\ Rudi Masniadi \\ Fakultas Ekonomi dan Manajemen, Universitas Samawa \\ rudimasni@gmail.com \\ Syarif Fitriyanto \\ Fakultas Ilmu Keguruan dan Pendidikan, Universitas Samawa \\ syarif.fisikaunsa@gmail.com \\ Wening Kusumawardani \\ Fakultas Pertanian,Universitas Samawa \\ Kusumawardani_wening@yahoo.co.id \\ Syafruddin \\ Fakultas Ekonomi dan Manajemen, Universitas Samawa \\ Syafagent@gmail.com
}

\begin{abstract}
Abstrak
Tujuan kegiatan pengabdian kepada masyarakat adalah untuk meningkatkan pengetahuan dan membangun kesadaran masyarakat tentang pentingnya pengelolaan dan pemanfaatan sampah perkotaan berbasis rumah tangga.Kegiatan dilaksanakan di RT 003 RW 009, Desa Labuhan Sumbawa, Kecamatan Labuhan Badas, Kabupaten Sumbawa Propinsi Nusa Tenggara Barat (Prop.NTB) mulai bulan September-Oktober 2019.Metode yang digunakan pada kegiatan ini adalah penyuluhan, pelatihan dan pendampingan pengolahan sampah skala rumah tangga.Hasil kegiatan menunjukkan bahwa terdapat peningkatan pengetahuan dan kesadaran
\end{abstract}




\section{(A) ABDIMAS \\ https://journal.uwgm.ac.id/index.php/abdimasmahakam}

E-ISSN: 2549-5755

Januari 2020, Vol. 4 No. 01

masyarakat terhadap dalam memperlakukan sampah, dan mengarah kepada paradigma pengelolaan persampahan yang lebih komprehensif dengan konsep 3R.Perubahan perilaku warga sasaran yang terdiri dari ibu-ibu, remaja telah memperlakukan sampah sebagai barang yang memiliki manfaat ekonomi dengan mengolah sampah rumah tangga menjadi menjadi kompos yang diaplikasikan pada KRPL Pancawarga dan kreativitas warungkopi sampah menuju Sumbawa Zero Waste.

Kata Kunci: pengelolaan sampah; 3R; berbasis masyarakat.

\section{Pendahuluan}

Asia Timur adalah wilayah dengan pertumbuhan produksi sampah tercepat di dunia.Pertumbuhan jumlah penduduk yang sejalan dengan meningkatnya nilai konsumsi masyarakat dalam memenuhi kebutuhan hidup, menjadi salah satu penyebab meningkatnya jumlah sampah yang semakin beragam.Indonesia merupakan salah satu dari lima Negara di Asia Timur yang bertanggung jawab terhadap 50\% keseluruhan sampah plastik di lautan (Jambeck et al., 2015). Indonesia diperkirakan menghasilkan sampah sekitar 85.000-ton setiap hari, dengan perkiraan kenaikan hingga 150.000-ton dihasilkan per hari pada tahun 2025 (Bank Dunia, 2012).

Peningkatan timbulan sampah dapat menyebabkan penurunan kualitas lingkungan karena dapat menyebabkan pencemaran tanah, air dan udara serta mempengaruhi kesehatan masyarakat, menjadikan sampah sebagai salah satu masalah serius yang harus segera di kelola, terutama di Propinsi Nusa Tenggara Barat.Data volume sampah di 10 kabupaten/kota di NTB menunjukkan bahwa jumlah sampah 3.388 ton dan belum terkelola mencapai 2.695,63 ton (83 persen) dari total sampah di NTB (Dinas LHK NTB, 2019).

Kabupaten Sumbawa adalah salah satu Kabupaten di Prop.NTB yang telah mengupayakan untuk menangani sampah. Penananganan sampah dilakukan melalui sarana prasarana pengelolaan sampah yang mengalami keterbatasan penampungan sehingga menambah beban Tempat Pembuangan Akhir, dengan jumlah sampah sebesar 63-ton tersebar di 24 kecamatan, dengan jumlah yang dapat dilayani 17,35 persen, dan 82,65 persen tidak terlayani (Dinas LHK Kabupaten Sumbawa, 2019).

Tingginya jumlah persentase sampah tidak terlayani memperlihatkan terbatasnya sarana prasarana yang disediakan oleh pemerintah daerah dan kurangnya kesadaran masyarakat, terutama di wilayah pesisir Kecamatan Labuhan Badas.Hartono et al. (2017a) menunjukkan bahwa jumlah volume sampah rumah tangga sebesar $6000 \mathrm{~kg} / \mathrm{hari}$ yang dihasilkan oleh masyarakat Desa Labuhan Sumbawa, dengan beberapa titik timbulan sampah berada pada wilayah di pantai jempol, pinggiran sungai Desa Karang Padak dan beberapa lahan kosong milik masyarakat. 
E-ISSN: 2549-5755

Januari 2020, Vol. 4 No. 01

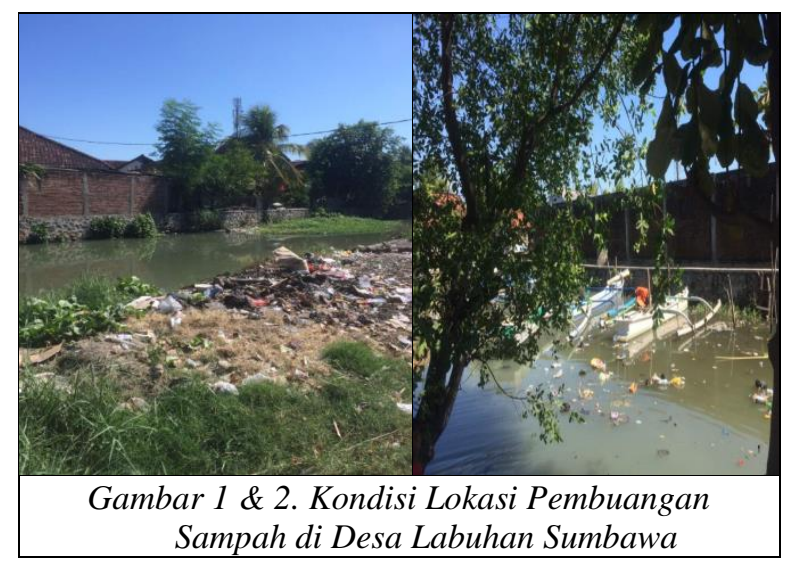

Hartono et al. (2019b) menjelaskan bahwa hasil identifikasi potensi permasalahan yang berkaitan dengan pengelolaan sampah di wilayah pesisir Desa Labuhan Sumbawa, menunjukkan bahwa peran serta masyarakat masih minim dimana pengetahuan dan kesadaran masyarakat terhadap pengelolaan sampah masih rendah. Masyarakat belum sepenuhnya mendukung pengelolaan sampah, hal ini terlihat dari perilaku masyarakat dalam membuang sampahnya langsung ke sungai, laut dan di tempat-tempat yang bukan peruntukkannya, sehingga harus segera dilakukan upaya pengelolaan yang komprehensip.

Permasalahan sampah sangat kompleksitas dan upaya mengurangi dampak dari limbah makanan terus dilakukan (Jurgilevich et al., 2016; Parfitt et al., 2010; Markard et al., 2012; Martin et al., 2016), terutama di daerah pesisir yang memiliki sistem yang multidimensi dengan manusia dan sub sistem biofisik berada dalam hubungan yang kontinyu, dinamis dan kompleks (Roca dan Villares, 2007).

Pengelolaan sampah berbasis masyarakat merupakan pengelolaan sampah yang melibatkan seluruh lapisan masyarakat.Yang bertujaun agar mayarakat menyadari bahwa permasalahan sampah merupakan tanggung jawab seluruh lapisan masyarakat akan memberi manfaat secara ekonomi, sehat bagi masyarakat, aman bagi lingkungan, dan menjadikan sampah sebagai sumberdaya.Setiadi (2015) menjelaskan bahwa pengelolaan sampah dengan pendekatan partisipatif, dapat membentuk kesadaran tinggi masyarakat dalam merespon masalah sampah dan bertindak atas dasar kepentingan bersama.

Tujuan kegiatan adalah untuk menumbuh kembangkan kesadaran, pengetahuan dan keterampilan dalam pengelolaan dan pemanfaatan sampah Rumah Tangga pada masyarakat Desa Labuhan Sumbawa, Kecamatan Labuhan Badas,Kabupaten Sumbawa.

\section{Metode}

Lokasi kegiatan dilaksanakan di RT 003 RW 009, Desa Labuhan Sumbawa-Kecamatan Labuhan Badas dari bulan September-Oktober 2019.

Pemilihan lokasi didasarkan pada pertimbangan bahwa: (1) Lokasi kegiatan pengabdian merupakan lokasi penelitian sebelumnya, yaitu Social Mapping dan Need Assessment masyarakat di Sekitar Area Kerja PT PLN (PLTD) Labuhan Sumbawa. Pencapaian tujuan pengabdian dilakukan denganmetode:

1. Memberikan pelatihan kepada kelompok masyarakat. Kegiatan ini meliputi pemberian materi dengan metode ceramah tentang pentingnya pemanfaatan dan pengolahan sampah, 


\section{(A) ABDIMAS}

https://journal.uwgm.ac.id/index.php/abdimasmahakam

E-ISSN: 2549-5755

Januari 2020, Vol. 4 No. 01

kelembagaan sampah dan merupiahkan sampah.Khusus untuk pengolahan sampah menjadi pupuk organik dengan pemanfaatan kotoran hewan (kohe).

2. Memfasilitasi hadirnya satu kawasan rumah pangan lestari (KRPL). Model Kawasan Rumah Pangan Lestari yang dikembangkan adalah sebagai pilot project dalam mendukung program pemerintah terkait pemenuhan pangan yang bergizi, seimbang dan beragam melalui pemanfaatan lahan pekarangan masyarakat.

\section{Hasil dan Pembahasan}

\section{Sosialisasi dan Penyiapan Kelompok}

Penyiapan kelompok bertujuan untuk menyiapkan sarana bagi masyarakat sehingga memudahkan koordinasi, pelaksanaan dan pencapaian luaran program.Penyiapan kelompok dimulai dengan berkoordinasi dengan Pemdes Labuhan Sumbawa, dalam rangka membentuk 2 kelompok pengelolah sampah yaitu kelompok remaja dan kelompok ibu-ibu rumah tangga.Kelompok remaja sebagai kelompok percontohan yang beranggotakan 30 orang, dan kelompok ibu-ibu rumah tangga berjumlah 20 orang.

Pembentukkan dua kelompok tersebut merupakan model yang bertujuan jangka panjang dapat menggerakkan masyarakat secara luas dalam pengelolaan dan pemanfaatan sampah berbasis rumah tangga. Koordinasi dengan Pemdes Labuhan Sumbawa dan kegiatan penyiapan kelompok dilaksanakan pada tanggal 10 Juli 2019 bertempat di rumah Kepala Desa Labuhan Sumbawa (Gambar 2).

Hasil kegiatan berupa beberapa kesepakatan warga sasaran yang akan dijadikan sebagai warga percontohan untuk program pengelolaan dan pemanfaatan sampah berbasis rumah tangga adalah warga Panca Warga yang termasuk ke dalam warga RT 003 RW 009. Selanjutnya, kelompok pengolah sampah yang akan dibentuk berasal dari pemuda dan pemudi di Desa Labuhan Sumbawa yang tergabung dalam kelompok Remaja Mesjid Panca Warga.

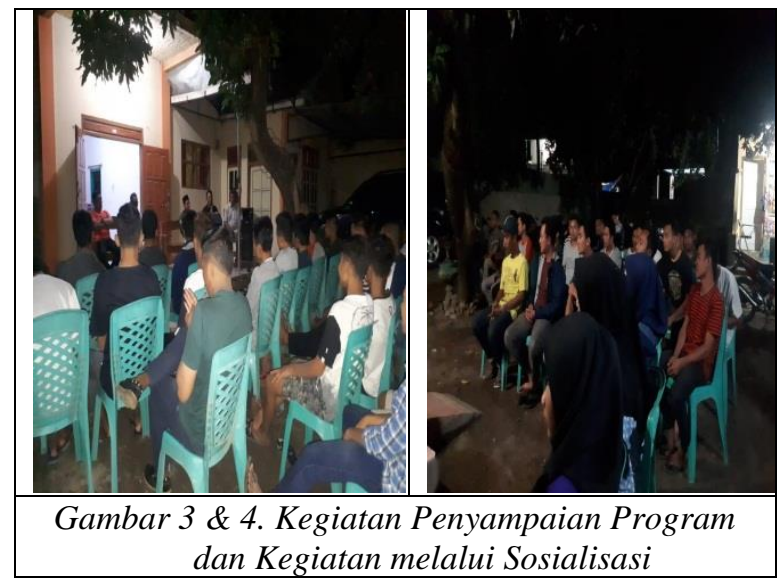

Hasil kegiatan sosialisasi menghasilkan kesapaham dengan pemerintah desa terkait gambaran pelaksanaan program, yaitu terbentuknya kelompok dari pemuda yang akan diberikan edukasi tentang tahapan model pembentukan tim. Hasil kegiatan pembangunan tim menghasilkan empat koordinator, yaitu koordinator kompos, produk kerajinan, senam, dan KRPL yang telah memahami fungsi dan tugasnya. 


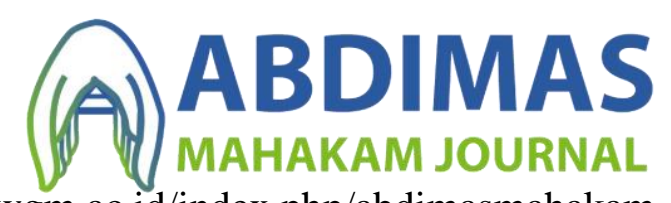

https://journal.uwgm.ac.id/index.php/abdimasmahakam

E-ISSN: 2549-5755

Januari 2020, Vol. 4 No. 01

\section{Pelatihan dan Pendampingan}

Kegiatan pelatihan dan pendampingan merupakan kegiatan yang dilakukan setelah dibentuknya kelompok.Kegiatan pelatihan berkaitan dengan upaya peningkatan pengetahuan, sikap dan ketrampilan masyarakat dalam pengelolaan sampah perkotaan.Pelatihan pengolahan sampah organik rumah tangga menjadi kompos dengan konsep $3 \mathrm{R}$.

Salah satu kegiatan yang dilakukan adalah pelatihan membuat hayati kompos dari sampah organik (Gambar 3).Hayati kompos adalah kompos yang berbahan dasar kotoran hewan sapi/ ayam/kambing/sampah organic rumah tangga, arang sekam dengan adanya tambahan starter mikroorganisme yang disebut MOL (Mikro organism Lokal).Metode ini merupakan metode yang tergolong mudah, murah dan cepat. MOL terdiri dari dua jenis yaitu MOL gula dan MOL garam.

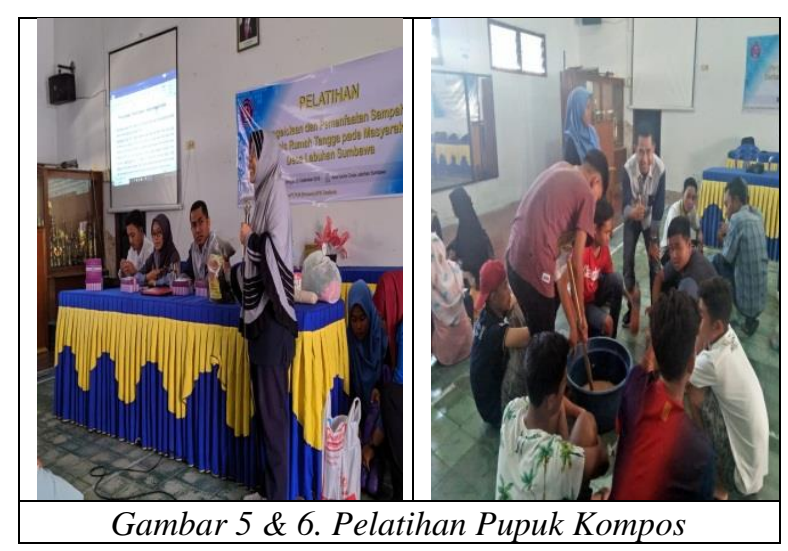

Penerapan metode pelatihan yang lebih bersifat praktisdapat menumbuhkan proses dialogis antara peserta dan pelatih berupa sharing pengalaman antar peserta. Kesadaran masyarakat untuk menerapkan konsep ini akan memicu tumbuhnya pengelolaan sampah berbasis masyarakat di samping kegiatan yang berusaha untuk meminimasi sampah.

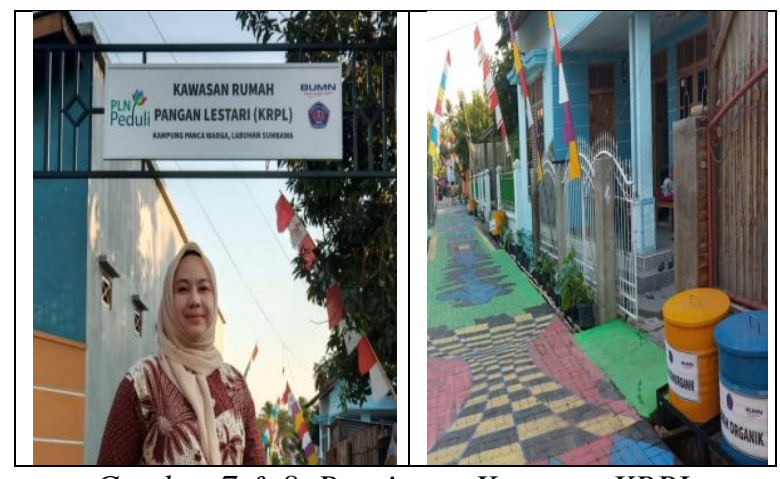

Gambar 7 \& 8. Penyiapan Kawasan KRPL 
https://journal.uwgm.ac.id/index.php/abdimasmahakam

E-ISSN: 2549-5755

Januari 2020, Vol. 4 No. 01

\section{Evaluasi dan Monitoring}

Tahap evaluasi pelaksanaan program bertujuan untuk mengukur tingkat keberhasilan kegiatan yang diterapkan.Evaluasi keseluruhan dilakukan setelah program atau kegiatan selesai dilaksanakan. Evaluasi dilakukan pada beberapa hal sebagai berikut:

1) Tingkat partisipasi mitra pada setiap kegiatan. Evaluasi terhadap tingkat partisipasi dilakukan pada setiap rangkaian kegiatan dengan cara memonitoring dan mengevaluasi jumlah kehadiran anggota kelompok mitra (kelompok Panca Warga). hasil evaluasi didapatkan bahwa masyarakat Panca Wargamemiliki partispasi yang tinggi pada persiapan,perencanaan, design, pelaksanaan maupun monitoring dan evaluasi yang dibuktikan oleh tingkat kehadiran peserta sesuai dengan yang diharapkan, disamping itu antusias masyarakat mengikuti kegiatan juga sangat besar dimana peserta mengikuti seluruh rangkaian kegiatan hingga kegiatan berakhir.

2) Tingkat pengetahuan mitra dalam memahami caramembuat kompos. Berdasarkan pengamatan saat pelaksanaan kegiatan pelatihan terlihat masyarakat memahami dan mampu membuat pupuk kompos.

3) Mitra memiliki kreatifitas dalam menyelesaikan permasalahan sampah, setelah dilakukan pendampingan. Kreatifitas Warung Kopi Sampah menjadi unik, dengan desain kegiatan yang menarik masyarakat lainnya sebagai tempat meningkatkan keimanan, dan tempat diskusi terkait pengelolaan lingkungan di Pancawarga.

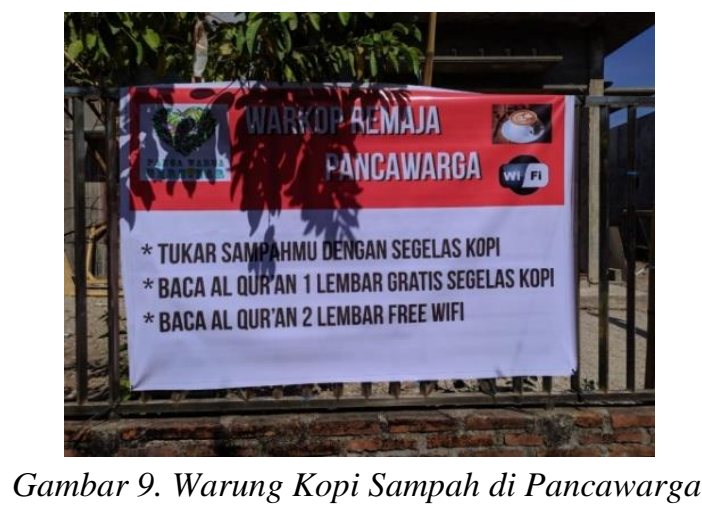

\section{Simpulan dan rekomendasi}

Pengolaan sampah partisipatif secara bertahap mampu mendorong masyarakat untuk bersedia terlibat, melakukan dan merasakan manfaat.

\section{Ucapan Terima Kasih}

Ucapan terima kasih disampaikan kepada PT. PLN (Persero) UPK Tambora atas dukungan finansial yang diberikan tahun 2019. 


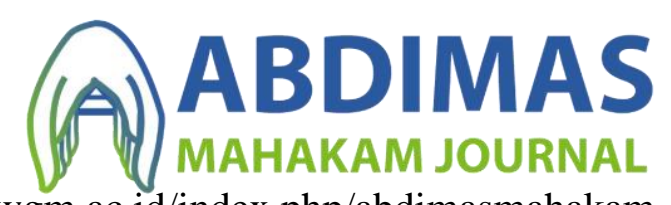

https://journal.uwgm.ac.id/index.php/abdimasmahakam

E-ISSN: 2549-5755

Januari 2020, Vol. 4 No. 01

\section{Daftar Pustaka}

Gangwar, Neha dan Saraswat, Y. (2016). Waste Management: A Corporate Social Responsibility or a Legal Obligation. Imperial Journal of Interdisciplinary Research (IJIR) 2(11). ISSN: 2454-1362, https://www.onlinejournal.in/IJIRV2I11/192.pdf.

Hartono, Yadi.,Ayu, I.W., Mardhia, D., Kautsari, N., Nanang. (2017). Social Mapping dan Need Assessment masyarakat Di Sekitar Area Kerja PT PLN (PLTD) Labuhan Sumbawa.Program kerjasama PT PLN (PLTD) Labuhan Sumbawa dan LPPM Universitas Samawa.LPPM Universitas Samawa.Sumbawa Besar

Hartono, Yadi., Ayu, I.W., Mardhia, D., Masniadi, R. (2019). Pengelolaan dan Pemanfaatan Sampah Berbasis Rumah Tangga pada Masyarakat.Program kerjasama PT. PLN (Persero) UPK Tambora dan LPPM Universitas Samawa.LPPM Universitas Samawa.Sumbawa Besar

Jurgilevich, A., Birge, T., Kentala-Lehtonen, J., Korhonen-Kurki, K.,Pietikäinen, J., Saikku, L., Schösler, H. (2016). Transition towards Circular Economy in the Food System. Sustainability: 8, (69).

Jenna R. Jambeck., Roland Geyer., Chris Wilcox., Theodore R. Siegler., Miriam Perryman., Anthony Andrady., Ramani Narayan., Kara Lavender Law. (2015). Plastic waste inputs from land into the ocean. Science :347

(6223) pp. 768-771. DOI: $10.1126 /$ science.

Parfitt, J., Barthel, M., Macnaughton, S. (2010). Food waste within food supply chains: Quantification and potential for change to 2050. 2010. Philos. Trans. R. Soc. Lond; 365 (3065-3081).

Martin, M., Danielsson, L. Environmental Implications of Dynamic Policies on Food Consumption and Waste Handling in the European Union. Sustainability: 8 (282)

Markard, J., Raven, R., Truffer, B. (2012). Sustainability transitions: An emerging field of research and its prospects. Res. Policy: 41(955-967).

Qonaah, S. (2018). Implementasi Corporate Social Responsibility PT PLN Distribusi Jawa Tengah dalam Pemberdayaan Masyarakat dan Lingkungan Melalui Program "PLN PEDULI." Jurnal Komunikasi, 9(1), 46-52.

Widiarti, I.W. (2012). Pengelolaan Sampah Berbasis "Zero Waste" Skala Rumah Tangga Secara Mandiri. Jurnal Sains dan Teknologi Lingkungan: (4)2, hal 101-113. ISSN: 2085-1227.

World Bank (2012) What a Waste: A Global Review of Solid Waste Management.Washington. USA. 